\title{
Rola przedsięwzięć w wieloletnich prognozach finansowych samorządów wojewódzkich
}

\begin{abstract}
Iwona Podpora*
Celem autorki jest ocena roli przedsięwzięć $w$ wieloletnich prognozach finansowych dla samorząów wojewódzkich. Szczególnq uwagę zwrócono na zróżnicowanie struktury przedsięwzięć $w$ poszczególnych województwach, $z$ uwzględnieniem przedsięwzięć majątkowych oraz finansowanych ze środków pochodzacych ze środków UE. W artykule podkreślono, że zakres przedsięwzięc determinuje wieloletni horyzont planowania budżetowego w JST. Okres badawczy obejmuje lata 2014-2017.
\end{abstract}

Słowa kluczowe: wieloletnie planowanie budżetowe, finanse samorządowe, budżetowanie publiczne.

Nadesłany: 06.06.17 | Zaakceptowany do druku: 21.08.17

\section{The Role of Projects in Long-Term Financial Forecasts of Voivodship Local Goverments in Poland}

The purpose of the paper is to evaluate the role of projects in long-term financial forecasts for voivodship self-governments (regions) in Poland. Particular attention has been paid to the diversification of the structures of long-term projects in particular voivodships, including property projects and projects financed by EU funds. The paper emphasizes that the multiyear budget planning horizon in local government units is determined by the scope of projects. The research period covers the years 2014-2017.

Keywords: multi-year budgeting, local government finance, public budgeting.

Submitted: 06.06.17 | Accepted: 21.08.17

JEL: H72, H79, R53

Iwona Podpora, mgr - Państwowa Wyższa Szkoła Zawodowa w Nysie.

Adres do korespondencji: Państwowa Wyższa Szkoła Zawodowa w Nysie, ul. Armii Krajowej 7 , 48-300 Nysa; e-mail: iwona.podpora@pwsz.nysa.pl. 


\section{Wprowadzenie}

Jednym z przejawów istotnych przeobrażeń procesów zarządzania finansami publicznymi jest wydłużenie horyzontu planowania budżetowego (Franek, 2013). Dotyczy to zarówno budżetu państwa, jak i jednostek samorządu terytorialnego, co jest związane z obowiązkiem przygotowywania od 2010 roku Wieloletniego Planu Finansowego Państwa oraz Wieloletnich Prognoz Finansowych (WPF) przez jednostki samorządu terytorialnego. Problematyka stosowania tego instrumentu jest przedmiotem szerokiego zainteresowania w literaturze przedmiotu. W dotychczasowym dorobku zauważyć można koncentrację na aspektach proceduralnych, czego wyrazem są między innymi publikacje autorstwa A. Walasika (2011), K. Owsiak (2014), L. Patrzałka (2011). Panuje przy tym przekonanie o ograniczonym zastosowaniu WPF do przedstawiania zamierzonej aktywności jednostek samorządu terytorialnego, co nadaje temu dokumentowi wymiar formalny, a nie zarządczy i świadczy o jego iluzoryczności (Filipiak, Dylewski, 2010; Kosikowski, 2011). Zasadniczym tego powodem jest trudność w określeniu realności prognoz wynikających z zapisów WPF, co pozwala na dużą swobode w określaniu kwot zapewniających wypełnianie norm ostrożnościowych, jakim podlegają JST (Dylewski, 2016; Franek, 2012). W obecnej postaci WPF jednostek samorządu terytorialnego ma więc w zasadzie wymiar czysto techniczny, sprowadzający się do ujęcia podstawowych wielkości budżetowych w ramy wieloletnie, głównie w odniesieniu do możliwości wypełniania norm ostrożnościowych w zakresie długu. Istotnym elementem tej prognozy jest wykaz przedsięwzięć. Stanowi on projekcję bieżących decyzji budżetowych, których skutki finansowe mogą być obserwowane w przyszłości, w kontekście zarówno generowania wydatków, jak i widzenia konieczności ich sfinansowania. W literaturze $\mathrm{z}$ zakresu finansów samorządowych niewiele miejsca poświęca się analizie WPF w odniesieniu do struktury przedsięwzięć $\mathrm{w}$ nich ukazanych. M. Gałecka (2016) zwraca uwage na znaczenie przedsięwzięć w tworzeniu WPF, negatywnie oceniając próby standaryzacji podejścia do prezentacji tej części WPF. Dzięki tej standaryzacji możliwa jest jednak analiza porównawcza zakresu wykorzysty- wania kategorii przedsięwzięć w gospodarce finansowej JST. Należy bowiem uznać, że to właśnie przedsięwzięcia uzasadniają przygotowywanie WPF, bo to ich realizacja wpływa na przyszłą strukturę budżetu.

Stad też celem autorki tego artykułu jest ocena roli przedsięwzięć $\mathrm{w}$ wieloletnich prognozach finansowych JST na przykładzie samorządów szczebla wojewódzkiego. Okres badawczy obejmuje prognozy uchwalone na lata od 2014 do 2017 roku, przy czym w analizach uwzględniono te uchwały dotyczące WPF, które były przyjmowane wraz z uchwałami budżetowymi. Uznano przy tym, że ze względu na ponadlokalny charakter zadań samorządu wojewódzkiego oraz znaczącą rolę wydatków majątkowych województw $\mathrm{w}$ porównaniu $\mathrm{z}$ pozostałymi rodzajami JST przedsiewzieccia realizowane przez województwa w znaczący sposób przyczyniają się realizacji celów strategicznych państwa. Warto też zauważyć, że oparcie dochodów podatkowych województw na wpływach z bardzo niestabilnego podatku, jakim jest CIT, wystawia województwa na ryzyko dużych wahań dochodów oraz na ryzyko popełnienia istotnego błędu $\mathrm{w}$ ich prognozowaniu, co w przypadku samorządów województw odpowiadających za zarządzanie rozwojem regionu i realizujących wieloletnie projekty o zasięgu regionalnym, zwłaszcza przy wykorzystaniu środków europejskich, może prowadzić do niezrealizowania ich celów strategicznych, będących jednocześnie celami strategicznymi państwa.

\section{Kategoria przedsięwzięć na potrzeby przygotowania wieloletnich prognoz finansowych jednostek samorządu terytorialnego}

Jednym $\mathrm{z}$ istotnych elementów wieloletnich prognoz finansowych jest wykaz przedsięwzięć, który zgodnie z zapisami art. 226 ustawy z dnia 27 sierpnia 2009 r. o finansach publicznych (Dz.U. 2009 nr 157 poz. $1240 \mathrm{ze} \mathrm{zm}$.) powinien określać dla każdego przedsięwzięcia: nazwę i cel; jednostkę organizacyjną odpowiedzialną za realizację lub koordynującą wykonywanie przedsięwzięcia; okres realizacji i łączne nakłady finansowe; limity wydatków w poszczególnych latach; limit zobowiązań. Przedsiewzięcia te należy rozumieć jako 
wieloletnie programy, projekty lub zadania, w tym związane z: programami finansowanymi z udziałem środków pochodzących z budżetu Unii Europejskiej i pozostałych środków zagranicznych niepodlegajacych zwrotowi oraz $\mathrm{z}$ umowami o partnerstwie publiczno-prywatnym. Taki zakres przedmiotowy przedsięwzięć pojawił się wraz z ustawa z dnia 7 grudnia 2012 r. o zmianie niektórych ustaw w związku $\mathrm{z}$ realizacją ustawy budżetowej (Dz.U. 2012 poz. 1456) W pierwotnej wersji ustawy o finansach publicznych uchwalonej 27.09.2009 roku (Dz.U. 2009 nr 157 poz. 1240) funkcjonował zapis rozszerzający pojęcie przedsięwzięć także o: umowy, których realizacja w roku budżetowym i w latach następnych jest niezbędna do zapewnienia ciagłości działania jednostki i z których wynikające płatności wykraczają poza rok budżetowy; oraz gwarancje i poręczenia udzielane przez jednostki samorządu terytorialnego. Podejście to było przedmiotem powszechnej krytyki (Człołpińska, 2011; Ruśkowski i Salachna, 2010). Zwracano bowiem uwagę, że zaliczanie umów zapewniających ciągłość działania jednostki do kategorii przedsięwzięć nie pozwala na wskazanie łącznych nakładów finansowych na przedsiewzięcie oraz określenie limitu wydatków w poszczególnych latach. Podkreślano także, że nie sprzyja to przejrzystości i porównywalności prognoz tworzonych przez poszczególne jednostki, gdyż pozwala na daleko idaca uznaniowość (Trykozko, 2010). Stąd też w pełni uzasadnione było zawężenie kategorii przedsiewzięć dokonane w 2012 roku (Dz.U. 2012 poz. 1456). W WPF sporządzanych do wejścia w życie tych przepisów można spotkać się z przykładami województw, które bardzo szeroko traktowały kategorię przedsięwzięć, wskazując, że prawie $100 \%$ ich wydatków podlega tej kategorii. Tak było w przypadku WPF województwa dolnośląskiego, gdzie w WPF uchwalonej na lata 2011-2023 wartość przedsięwzięć przypisanych do roku 2011 stanowiła prawie $95 \%$ wydatków ogółem. Dla porównania w WPF województwa lubuskiego uchwalonej na lata 2011-2024 przedsięwzięcia stanowiły jedynie nieco ponad $18 \%$ wydatków ogółem. Do uporządkowania prezentacji przedsięwzięć na potrzeby tworzenia WPF przyczyniło sie także wejście w życie rozporządzenia Ministra Finansów z dnia 10 stycznia 2013 r. w sprawie wieloletniej prognozy finansowej jednostki samorządu terytorialnego (Dz.U 2013 poz. 86 ze zm.). Pozwoliło ono znacząco ujednolicić sposób przedstawiania przedsięwzięć przez poszczególne jednostki samorządu terytorialnego.

Mimo tych zmian w literaturze spotkać sie można $\mathrm{z}$ poglądem, że definicja przedsięwzięć jest zbyt ogólna i nie precyzuje szczegółowych cech przedsięwzięcia, co prowadzi do znacznej uznaniowości przy opracowywaniu wykazu. Czesto bowiem do przedsięwzięć kwalifikowane są umowy wieloletnie, bez zwracania uwagi na to, czy określony docelowy efekt użytkowy wymaga w danych warunkach technicznoorganizacyjnych i ekonomicznych realizacji w okresie dłuższym niż rok. Należy jednak pamiętać, że podstawową przesłanką kwalifikowania programów, projektów i zadań do wykazu przedsięwzieć jest wieloletniość ich realizacji w celu osiągnięcia założonego efektu. Dłuższy okres realizacji nie powinien więc być jedynym kryterium kwalifikacji, bo gdyby tak było, to ustawowe wskazanie na programy, projekty i zadania jako przedsięwzięcia byłoby zbędne. Oznacza to, że wieloletnie programy, projekty i zadania podlegają ujęciu w załączniku do wieloletniej prognozy finansowej i to wtedy, gdy osiagnięcie założonego efektu użytkowego wymaga wieloletniej realizacji. Powiązanie okresu realizacji z określonym celem jest nieodłączną cechą przedsięwzięcia (Stęplowski, 2016).

Zauważyć przy tym należy, że kwota wydatków zaplanowana na realizowane przedsięwzięcia powinna umożliwiać ich terminowe zakończenie, co jest dodatkowym podkreśleniem wymogu w zakresie realności WPF.

W tabeli 1 uszeregowano województwa według udziału wydatków na przedsięwzięcia zapisane $\mathrm{w}$ wieloletnich prognozach finansowych uchwalanych w okresie od 2014 do 2017 roku. O znaczeniu przedsięwzięć w realizacji polityki wydatkowej województw świadczyć może, że w czterech z nich, tj.: małopolskim, świętokrzyskim, dolnośląskim i śląskim, w każdym z czterech badanych lat wydatki na przedsiewzieccia przekraczały $50 \%$ wydatków ogółem. Można więc uznać, że relacja ta wskazuje, iż w ponad połowie budżet tych województw determinowany jest zamierzeniami wieloletnimi, a wydatki o horyzoncie rocznym stanowią mniejszość. Taka sytuacja jest potwierdzeniem sensu budowania wieloletnich prognoz finanso- 
Tabela 1. Udział wydatków na przedsięwzięcia w wydatkach ogółem województw (w \%)

\begin{tabular}{|l|c|c|c|c|}
\hline \multicolumn{1}{|c|}{ Wyszczególnienie } & $\mathbf{2 0 1 4}$ & $\mathbf{2 0 1 5}$ & $\mathbf{2 0 1 6}$ & $\mathbf{2 0 1 7}$ \\
\hline małopolskie & 65,1 & 55,1 & 66,2 & 71,2 \\
\hline świętokrzyskie & 70,0 & 65,9 & 63,9 & 70,9 \\
\hline podkarpackie & 68,3 & 65,4 & 39,5 & 67,9 \\
\hline lubuskie & 34,7 & 39,3 & 37,0 & 66,9 \\
\hline zachodniopomorskie & 53,2 & 54,3 & 48,3 & 63,5 \\
\hline wielkopolskie & 57,0 & 38,8 & 50,2 & 61,1 \\
\hline dolnośląskie & 57,8 & 57,4 & 56,5 & 59,3 \\
\hline śląskie & 67,8 & 55,0 & 50,9 & 56,0 \\
\hline warmińsko-mazurskie & 74,4 & 68,8 & 40,7 & 51,7 \\
\hline kujawsko-pomorskie & 58,1 & 56,9 & 48,3 & 51,5 \\
\hline podlaskie & 64,4 & 61,4 & 37,0 & 45,8 \\
\hline łódzkie & 44,1 & 39,5 & 40,9 & 42,5 \\
\hline pomorskie & 29,1 & 33,7 & 40,4 & 40,8 \\
\hline opolskie & 38,0 & 23,2 & 59,2 & 39,0 \\
\hline mazowieckie & 45,8 & 46,8 & 29,4 & 34,5 \\
\hline lubelskie & 77,8 & 25,7 & 46,6 & 25,9 \\
\hline
\end{tabular}

Źródło: opracowanie własne na podstawie WPF województw.

wych i ukazuje zasadność wydłużania horyzontu czasowego budżetu poza okres najbliższego roku budżetowego. Jednocześnie wskazać można te województwa, w których w żadnym $\mathrm{z}$ badanych lat wydatki na przedsięwzięcia nie przekraczały $50 \%$. Są nimi łódzkie, pomorskie i mazowieckie. W przypadku tych województw w konstrukcji ich budżetów przeważaja wydatki o rocznym okresie zapadalności. Można te województwa uznać za najmniej podatne na wydłużenie horyzontu czasowego budżetów JST Oznacza to, że ich przyszłe budżety są w ograniczonym stopniu zdeterminowane zobowiazaniami z zapisanych w WPF przedsięwzięć.

\section{Rola przedsięwzięć majątkowych w wieloletnich prognozach finansowych województw}

Specyficzną cechą województw, na tle pozostałych rodzajów jednostek samorządu terytorialnego, jest znacząco wyższy udział wydatków majątkowych w wydatkach ogółem. Swiadczą o tym dane przedstawione w tabeli 2.

Tabela 2. Udział wydatków majątkowych w wydatkach ogółem JST w latach 2011-2016 (w \%)

\begin{tabular}{|lr|c|c|c|c|c|}
\hline $\begin{array}{l}\text { Wyszcze- } \\
\text { gólnienie }\end{array}$ & $\mathbf{2 0 1 1}$ & $\mathbf{2 0 1 2}$ & $\mathbf{2 0 1 3}$ & $\mathbf{2 0 1 4}$ & $\mathbf{2 0 1 5}$ & $\mathbf{2 0 1 6}$ \\
\hline $\begin{array}{l}\text { woje- } \\
\text { wództwa }\end{array}$ & 40,5 & 37,8 & 39,7 & 43,0 & 45,1 & 26,2 \\
\hline gminy & 22,9 & 18,1 & 16,6 & 18,2 & 16,9 & 11,2 \\
\hline powiaty & 18,7 & 12,5 & 12,5 & 14,7 & 14,6 & 12,9 \\
\hline $\begin{array}{l}\text { miasta } \\
\text { na prawach } \\
\text { powiatu }\end{array}$ & 21,2 & 19,9 & 19,1 & 20,9 & 18,5 & 11,9 \\
\hline
\end{tabular}

Źródło: sprawozdania z wykonania budżetów JST za lata 2011-2016.

Koncentrację na wydatkach majątkowych szczególnie mocno można dostrzec w przypadku województw podkarpackiego i podlaskiego, w których w pieciu na sześć badanych lat wydatki majątkowe przekraczały $40 \%$ wydatków ogółem. Znaczące obniżenie tego udziału w 2016 roku, dostrzegalne we wszystkich rodzajach JST, jest wynikiem opóźnień w realizacji projektów finansowanych ze środków unijnych w ramach perspektywy finansowej na lata 2014-2020. O skali wpływu środków z UE na poziom wydatków majątkowych województw może świadczyć fakt, że w 2016 roku, tylko w dwóch województwach: małopolskim i opolskim wydatki majątkowe przekroczyły $40 \%$ wydatków ogółem, podczas gdy rok wcześniej takich województw było osiem. Jednocześnie w 2016 roku trzy województwa: warmińsko-mazurskie, podkarpackie i mazowieckie, wykazały udział wydatków majątkowych na poziomie niższym niż $20 \%$ wydatków ogółem, co było wielkością niespotykaną w żadnym z województw w poprzednich badanych latach.

Stąd też warto poświęcić szczególną uwagę roli przedsięwzięć majątkowych $\mathrm{w}$ tworzeniu wieloletnich prognoz finansowych województw. W tabeli 3 zaprezentowano wielkości udziałów wydatków na przedsięwzięcia majątkowe w wydatkach ogółem na przedsięwzięcia zapisanych w wieloletnich prognozach finansowych uchwalonych na lata 2014-2017. 
Tabela 3. Udział wydatków na przedsięwzięcia majątkowe województw w całkowitych wydatkach na przedsięwzięcia ( $w$ \%)

\begin{tabular}{|l|c|c|c|c|}
\hline Wyszczególnienie & $\mathbf{2 0 1 4}$ & $\mathbf{2 0 1 5}$ & $\mathbf{2 0 1 6}$ & $\mathbf{2 0 1 7}$ \\
\hline podlaskie & 80,3 & 78,3 & 64,4 & 79,9 \\
\hline lubuskie & 46,4 & 60,4 & 59,3 & 79,4 \\
\hline podkarpackie & 79,7 & 80,2 & 41,3 & 75,8 \\
\hline pomorskie & 88,6 & 87,1 & 75,9 & 74,6 \\
\hline małopolskie & 63,0 & 60,6 & 65,6 & 71,6 \\
\hline dolnośląskie & 76,4 & 77,7 & 70,3 & 70,8 \\
\hline świętokrzyskie & 70,5 & 68,4 & 63,0 & 69,2 \\
\hline zachodniopomorskie & 60,8 & 51,3 & 46,4 & 67,8 \\
\hline wielkopolskie & 62,2 & 51,1 & 54,6 & 63,4 \\
\hline śląskie & 74,6 & 69,2 & 62,3 & 61,3 \\
\hline warmińsko-mazurskie & 84,7 & 79,4 & 43,0 & 57,3 \\
\hline kujawsko-pomorskie & 56,2 & 50,8 & 55,6 & 48,2 \\
\hline łódzkie & 63,1 & 50,4 & 42,8 & 45,4 \\
\hline opolskie & 21,1 & 55,7 & 55,7 & 43,5 \\
\hline mazowieckie & 59,4 & 64,1 & 39,8 & 43,1 \\
\hline lubelskie & 85,0 & 75,1 & 61,2 & 27,6 \\
\hline
\end{tabular}

Źródło: opracowanie własne na podstawie WPF województw.

Aż w siedmiu z województw w każdym z badanych lat wydatki na przedsięwzięcia majątkowe przeważały w ujęciu wartościowym nad przedsięwzięciami bieżącymi, a w przypadku województw pomorskiego i dolnośląskiego udział wydatków na przedsięwzięcia majątkowe w całości wydatków na przedsięwzięcia w badanych okresie przekraczał $70 \%$. Ponadto w żadnym z województw liczba lat, w których wydatk bieżące na przedsięwzięcia w wydatkach ogółem na przedsięwzięcia przekraczały $50 \%$ nie była większa od liczby lat, w których przeważały wydatki majątkowe na przedsięwzięcia.

\section{Rola przedsięwzięć \\ finansowanych ze środków UE w WPF województw}

Znaczący wpływ na poziom wydatków przeznaczanych na realizację przedsięwzięć województw odgrywają środki pochodzące z funduszy Unii Europejskiej. W tabeli 4 zaprezentowano wielkość udziału wydatków na przedsięwzięcia finansowane z udziałem środków europejskich w całkowitych wydatkach na przedsięwzięcia planowane do realizacji w województwach w poszczególnych latach.

Tabela 4. Udział wydatków na przedsięwzięcia województw finansowane ze środków europejskich w całkowitych wydatkach na przedsięwzięcia planowanych na lata 2014-2017 (w \%)

\begin{tabular}{|l|c|c|c|c|}
\hline \multicolumn{1}{|c|}{ Wyszczególnienie } & $\mathbf{2 0 1 4}$ & $\mathbf{2 0 1 5}$ & $\mathbf{2 0 1 6}$ & $\mathbf{2 0 1 7}$ \\
\hline podlaskie & 96,1 & 89,4 & 62,6 & 91,1 \\
\hline małopolskie & 74,2 & 65,7 & 77,3 & 79,9 \\
\hline lubuskie & 48,6 & 45,7 & 41,7 & 77,2 \\
\hline podkarpackie & 70,9 & 36,4 & 47,0 & 76,0 \\
\hline pomorskie & 69,7 & 84,9 & 73,7 & 74,0 \\
\hline opolskie & 75,7 & 96,6 & 84,3 & 73,2 \\
\hline warmińsko-mazurskie & 79,9 & 54,2 & 57,1 & 69,1 \\
\hline wielkopolskie & 63,9 & 54,0 & 57,2 & 68,3 \\
\hline zachodniopomorskie & 63,2 & 51,8 & 54,7 & 65,8 \\
\hline kujawsko-pomorskie & 76,5 & 74,5 & 65,2 & 64,3 \\
\hline świętokrzyskie & 82,9 & 81,5 & 58,2 & 62,4 \\
\hline dolnośląskie & 66,1 & 59,8 & 48,2 & 58,4 \\
\hline lódzkie & 53,2 & 36,7 & 52,4 & 54,6 \\
\hline lubelskie & 85,7 & 44,8 & 76,1 & 51,6 \\
\hline śląskie & 72,4 & 57,3 & 35,4 & 48,6 \\
\hline mazowieckie & 52,0 & 42,1 & 17,2 & 30,0 \\
\hline
\end{tabular}

Źródło: opracowanie własne na podstawie WPF województw.

W dziewięciu województwach w każdym $\mathrm{z}$ badanych lat to właśnie przedsięwzięcia finansowane ze środków pochodzących z UE miały najwiekkszy wpływ na wysokość wydatków ogółem na przedsięwzięcia zapisanych w wieloletnich prognozach finansowych województw, gdyż w każdym $\mathrm{z}$ badanych lat stanowiły ponad $50 \%$ wydatków na przedsiewzieccia ogółem. Warto przy tym zauważyć, że spośród wszystkich województw województwo opolskie jest najbardziej „uzależnione” od środków europejskich w zakresie zakładanych do realizacji przedsięwzięć majątkowych, gdyż ich udział w całości wydatków na przed- 
sięwzięcia w każdym $\mathrm{z}$ analizowanych lat przekracza $70 \%$

\section{Zróżnicowanie liczby i wartości pojedynczych przedsięwzięć w WPF województw}

Warto jednocześnie zwrócić uwagę, że poszczególne województwa realizują różne strategie w zakresie liczby finansowanych przedsięwzięć, co pokazano w tabeli 5.

Po pierwsze, zauważalna jest zdecydowana przewaga województw, w których liczba przedsięwzięć finansowanych z udziałem środków europejskich jest większa od pozostałych przedsięwzięć. Po drugie, liczba przedsięwzięć majątkowych realizowanych przez wszystkie województwa jest znacząco wyższa od liczby przedsięwzięć bieżących. Po trzecie, wśród przedsięwzięć planowanych na 2017 rok tylko jedno ma być realizowane $\mathrm{w}$ ramach partnerstwa publiczno-prywatnego. Jest to przedsięwzięcie zapisane w WPF województwa świętokrzyskiego, związane $\mathrm{z}$ zapewnieniem szerokopasmowego dostępu do Internetu, planowane do realizacji do 2022 roku. Po czwarte, można zauważyć, że część województw stara się koncentrować środki na mniejszej liczbie przedsięwzięć, podczas gdy inne wykazuja skłonność do formułowania większej liczby przedsięwzięć. Mniejsza liczba przedsiewzieć widoczna jest szczególnie w przypadku województwa podlaskiego, w którym zauważyć można w badanym okresie znaczący, na tle innych województw, udział wydatków na przedsięwzięcia majątkowe, w tym zwłaszcza finansowane ze środków europejskich. Przykład województwa mazowieckiego pokazuje jednak, że stosunkowo niskie zaangażowanie w realizacje przedsięwziećc finansowanych ze środków UE wraz z mniejszym znaczeniem wydatków majątkowych na przedsię-

Tabela 5. Liczba przedsięwzięć województw w WPF uchwalonych na 2017 rok

\begin{tabular}{|l|c|c|c|c|c|}
\hline \multirow{2}{*}{ Wyszczególnienie } & \multirow{2}{*}{ Ogółem } & \multicolumn{2}{c|}{$\begin{array}{c}\text { Finansowane z udziałem } \\
\text { śodków } \mathbf{~ U E ~}\end{array}$} & \multicolumn{2}{c|}{ Pozostałe } \\
\cline { 3 - 6 } & & bieżące & majątkowe & bieżące & majątkowe \\
\hline mazowieckie & 281 & 47 & 42 & 66 & 126 \\
\hline małopolskie & 223 & 65 & 74 & 57 & 27 \\
\hline wielkopolskie & 185 & 40 & 70 & 35 & 40 \\
\hline kujawsko-pomorskie & 139 & 52 & 49 & 14 & 24 \\
\hline łódzkie & 117 & 20 & 36 & 11 & 50 \\
\hline podkarpackie & 113 & 21 & 45 & 30 & 17 \\
\hline świętokrzyskie & 106 & 27 & 24 & 35 & 20 \\
\hline śląskie & 101 & 30 & 19 & 25 & 27 \\
\hline lubuskie & 96 & 19 & 44 & 19 & 14 \\
\hline zachodniopomorskie & 95 & 26 & 42 & 16 & 11 \\
\hline pomorskie & 89 & 24 & 22 & 15 & 28 \\
\hline lubelskie & 71 & 20 & 29 & 13 & 9 \\
\hline opolskie & 66 & 31 & 27 & 2 & 6 \\
\hline warmińsko-mazurskie & 56 & 16 & 24 & 7 & 9 \\
\hline dolnośląskie & 27 & 8 & 8 & 6 & 5 \\
\hline podlaskie & 21 & 10 & 4 & 3 & 4 \\
\hline RAZEM & 1786 & 456 & 559 & 354 & 417 \\
\hline
\end{tabular}

Źródło: opracowanie własne na podstawie WPF województw. 
wzięcia może być powiązane $\mathrm{z}$ formułowaniem wielu różnorodnych przedsięwzięć, zazwyczaj o mniejszym poziomie wydatków.

W tabeli 6 przedstawiono zróżnicowanie wartości największych przedsięwzięć majątkowych planowanych do realizacji w kolejnych WPF województw. W tym celu dla każdego z województw wybrano największe, pod względem wartości określonej na pierwszy rok prognozy, przedsięwzięcie majątkowe zapisane w WPF $\mathrm{z}$ danego roku i odniesiono wysokość łącznych nakładów finansowych przewidzianych na wszystkie lata realizacji tego przedsięwzięcia do rocznych wydatków ogółem województwa zaplanowanych na pierwszy rok obowiązywania danej WPF. W ten sposób stworzono prostą miarę, ukazującą skalę możliwości sfinansowania pojedynczego przedsięwzięcia majątkowego wydatkami pojedynczego roku budżetowego.

$\mathrm{Z}$ danych zawartych w tabeli 6 szczególną uwagę należy poświęcić tym sytu-

Tabela 6. Relacja łącznej wartości największego przedsięwzięcia majątkowego z WPF na dany rok w województwie do wydatków budżetowych ogótem danego roku (w \%)

\begin{tabular}{|l|r|r|r|r|}
\hline Wyszczególnienie & $\mathbf{2 0 1 4}$ & $\mathbf{2 0 1 5}$ & $\mathbf{2 0 1 6}$ & $\mathbf{2 0 1 7}$ \\
\hline podlaskie & 52,9 & 22,4 & 14,4 & 121,3 \\
\hline świętokrzyskie & 26,8 & 28,5 & 142,7 & 80,0 \\
\hline śląskie & 23,9 & 52,2 & 71,7 & 65,2 \\
\hline dolnośląskie & 64,6 & 52,2 & 52,0 & 56,3 \\
\hline lubuskie & 13,5 & 6,5 & 58,4 & 42,8 \\
\hline łódzkie & 4,5 & 17,1 & 44,9 & 42,5 \\
\hline małopolskie & 8,3 & 10,1 & 21,8 & 31,1 \\
\hline zachodniopomorskie & 23,0 & 7,3 & 8,4 & 20,8 \\
\hline wielkopolskie & 36,2 & 9,1 & 3,2 & 20,6 \\
\hline podkarpackie & 17,2 & 10,5 & 7,6 & 13,9 \\
\hline lubelskie & 19,0 & 11,4 & 0,7 & 11,7 \\
\hline warmińsko-mazurskie & 9,8 & 7,7 & 42,7 & 11,6 \\
\hline opolskie & 13,9 & 27,2 & 30,8 & 9,9 \\
\hline pomorskie & 6,5 & 18,5 & 9,2 & 6,4 \\
\hline kujawsko-pomorskie & 8,9 & 9,3 & 25,8 & 3,8 \\
\hline mazowieckie & 5,0 & 3,3 & 16,0 & 1,9 \\
\hline
\end{tabular}

Źródło: opracowanie własne na podstawie WPF województw. acjom, w których wartość wskazanej relacji kształtuje się powyżej 100\%, co oznacza, że łączna wartość pojedynczego przedsięwzięcia planowanego na kolejne lata prognozy przekracza poziom rocznych wydatków budżetowych województwa. Takie przykłady wystepuja w województwie świętokrzyskim dla WPF uchwalonej na 2016 rok oraz województwie podlaskim dla WPF uchwalonej na 2017 rok. Są one dostatecznym dowodem na to, że trudno zadania JST, zwłaszcza związane realizacją inwestycji, odnosić do możliwości finansowych wynikających z rocznego budżetu. Tylko wydłużenie horyzontu planistycznego wraz z podjęciem decyzji o wieloletnim zaangażowaniu środków budżetowych pozwala na odpowiedzialną realizację wielu zamierzeń samorządowych, bez uszczerbku dla stabilności finansowej JST. Dotyczy to zwłaszcza samorządu wojewódzkiego, w którym na tle innych rodzajów JST wydatki majątkowe odgrywają szczególnie istotną rolę, a wiele zadań wymaga podejmowania kosztownych przedsięwzięć infrastrukturalnych. Zauważyć bowiem należy, że spośród tych przedsięwzięć majątkowych poszczególnych województw, które w badanym okresie w kolejnych latach budżetowych wykazywały najwyższe wartości wydatków, prawie połowę stanowiły inwestycje drogowe. Dodatkowo w przypadku województw: pomorskiego, małopolskiego i zachodniopomorskiego były to przedsięwzięcia związane $\mathrm{z}$ zakupem taboru dla kolei regionalnych.

\section{Podsumowanie}

Standaryzacja układu przedsięwzięć planowanych do realizacji przez poszczególne JST i uwzględnionych w ich JST pozwala, na podstawie badań przeprowadzonych na przykładzie samorządów wojewódzkich, na sformułowanie kilku uogólnień. Po pierwsze, konieczność prezentacji przedsięwzięć na potrzeby przygotowywania WPF pozwala na określenie stopnia wieloletniości wydatków najbliższego budżetu oraz skalę zdeterminowania ich przyszłych budżetów zobowiązaniami wynikającymi z zapisanych w WPF przedsięwzięć. Przykłady samorządów wojewódzkich wskazują na duże zróżnicowanie w tym zakresie, przy czym w większości z nich udział wydatków na przedsięwzięcia w wydatkach ogółem wskazuje na zasadność wydłużania horyzontu planistycznego na 
potrzeby JST. Po drugie, specyficzną cechą województw jest znaczny udział przedsięwzięć o charakterze majątkowym. Wynika to zarówno $\mathrm{z}$ faktu, że na tle innych typów JST wydatki majątkowe województw są względnie duże, jak i ze specyfiki zadań realizowanych przez samorządy wojewódzkie. Po trzecie, o strukturze przedsięwzięć w województwach decyduje zakres wykorzystania środków pochodzących z UE. Po czwarte, widoczna jest różna strategia w zakresie formułowania przedsięwzięć przez różne województwa. Jedne z nich koncentrują się na realizacji stosunkowo niewielkiej liczby przedsięwzięć, ale o przeciętnie wyższych kwotach, inne starają się w większym stopniu dywersyfikować portfel przedsięwzięć, zarówno bieżących, jak i majątkowych.

\section{Bibliografia}

Czołpińska, E. (2011). Wieloletnia prognoza finansowa - doświadczenia po roku stosowania. Przewidywania, praktyka i wnioski de lege ferenda. Finanse Komunalne, 12, 19-31.

Dylewski, M. (2016). Problemy wykorzystania WPF w zarządzaniu finansami jednostki samorządu terytorialnego. Studia Ekonomiczne. Zeszyty Naukowe Uniwersytetu Ekonomicznego w Katowicach, 273, 49-61.

Filipiak, B. i Dylewski, M. (2010). Kontrowersje związane ze sporządzaniem wieloletniej prognozy finansowej JST w związku z wdrożeniem budżetu zadaniowego. Finanse Komunalne, 12, 5-17.

Franek, S. (2012). Wieloletnia prognoza finansowa - przymus czy potrzeba? Annales Universitatis Mariae Curie-Sktodowska. Sectio H, Oeconomia, 46(3), 251-259.

Franek, S. (2013). Wieloletnie planowanie budżetowe w podsektorze rzadowym. Warszawa: Difin.
Gałecka, M. (2016). Zmiany w wykazie przedsięwzięć wieloletniej prognozy finansowej. Studia Ekonomiczne. Zeszyty Naukowe Uniwersytetu Ekonomicznego w Katowicach, 273, 75-85.

Kosikowski, C. (2011). Naprawa finansów publicznych w Polsce. Białystok: Wydawnictwo Temida 2.

Owsiak, K. (2014). Wieloletnia prognoza finansowa jako instrument zarządzania finansami jednostek samorządu terytorialnego. Zeszyty Naukowe UEK, 8(932), 166-176.

Patrzałek, L. (2011). Znaczenie wieloletniej prognozy finansowej w gospodarce finansowej jednostki samorządu terytorialnego i jej relacje $\mathrm{z}$ Wieloletnim Planem Finansowym państwa. Zeszyty Naukowe PTE, 10, 253-266.

Rozporzadzenie Ministra Finansów z dnia 10 stycznia 2013 r. w sprawie wieloletniej prognozy finansowej jednostki samorządu terytorialnego (Dz.U. 2013 poz. 86 ze zm.).

Ruśkowski, E. i Salachna, J. (red.) (2010). Nowa ustawa o finansach publicznych wraz z ustawa wprowadzająca. Komentarz praktyczny. Gdańsk: ODDK.

Steplowski, J. (2016). Opracowanie wykazu przedsięwzięć do wieloletniej prognozy finansowej sprawia ktopoty, http://serwisy.gazetaprawna.pl/samorzad/ artykuly/991220,w-niektorych-jst-uwzglednia-siezbyt-wiele-umow-w-innych-zbyt-malo.html,komentarze-najnowsze, 1

Trykozko, R. (2010). Ustawa o finansach publicznych. Komentarz dla jednostek samorzadu terytorialnego. Warszawa: Wydawnictwo Taxpress.

Ustawa z dnia 27 sierpnia 2009 r. o finansach publicznych (Dz.U. $2009 \mathrm{nr} 157$ poz. 1240 ze zm.).

Ustawa z dnia 7 grudnia 2012 r. o zmianie niektórych ustaw w związku z realizacją ustawy budżetowej (Dz.U. 2012 poz. 1456).

Walasik, A. (2011). Wątpliwości dotyczące wieloletniej prognozy finansowej. Samorząd Terytorialny, $1-2,43-50$ 